\title{
CTAG2 Gene Product
}

National Cancer Institute

\section{Source}

National Cancer Institute. CTAG2 Gene Product. NCI Thesaurus. Code C153123.

A protein encoded by the CTAG2 gene. 